\title{
PERENCANAAN JALUR SEPEDA DI KOTA SORONG
}

\author{
Irwan \\ Program Studi Teknik Sipil Universitas Muhammadiyah Sorong \\ Jalan Pendidikan No 27 Kota Sorong, Propinsi Papua Barat \\ Email :gepoirwan@gmail.com
}

\begin{abstract}
ABSTRAK
Sepeda merupakan salah satu alat transportasi darat untuk jarak dekat. Sekarang ini sepeda merupakan alat untuk bersenang-senang melakukan petualangan, dan menjaga kesehatan (Ismunandar, 1996: 1). Sepeda sebagai sarana untuk bersepeda memiliki banyak jenisnya, antara lain: sepeda gunung, sepeda lipat, sepeda jalan raya, dan lainlain. Meskipun demikian, tidak mengubah fungsi sepeda yaitu sebagai sarana transportasi bagi manusia untuk menghubungkan perpindahannya dari satu daerah ke daerah lain. Salah satu jenis sepeda adalah sepeda fixed gear atau masyarakat awam mengenal dengan sebutan sepeda Fixie. tanpa rem, dan tanpa gear dinamis atau gear mati. Sepeda ini menggunakan sistem fixed gear yang membuat ayunan pedal terus berputar seiring perputaran roda belakang. Menghentikan laju sepeda ini ketika berjalan atau melakukan pengereman pengendara harus mengurangi putaran pedal dengan gaya melawan arah perputaran pedal atau sistem door trape. Sistem door trape pada sepeda fixed gear justru membahayakan bagi pengendaranya ketika bersepeda.Tujuan penelitian ini yaitu untuk Untuk penerapan penggunaan lajur sepeda pada kawasan perkotaan Sorong mengalami kesulitan disebabkan besarnya volume kendaraan bermotor yang di dominasi oleh kendaraan bermotor pribadi. Sementara penerapan lajur sepeda pada kawasan perkotaan sorong tidak akan berhasil tanpa upaya pengurangan volume kendaraan bermotor pribadi itu sendiri Metode penelitian yang digunakan adalah Metode yang di gunakan dalam penelitian ini adalah pengumpulan data melalui kuesioner yang di distribusikan kepada 50 responden. Metode analisis yang bertujuan untuk menggambarkan respon masyarakat kota sorong terhadap rencana pengembangan jalur sepeda di wilayah perkotaan sorong.
\end{abstract}

Kata Kunci : jalur sepeda ; kota sorong ; papua barat 
PENDAHULUAN

\section{Latar Belakang}

Sepeda merupakan salah satu alat transportasi darat untuk jarak dekat. Sekarang ini sepeda merupakan alat untuk bersenang-senang, melakukan petualangan, dan menjaga kesehatan (Ismunandar, 1996: 1). Sepeda sebagai sarana untuk bersepeda memiliki banyak jenisnya, antara lain: sepeda gunung, sepeda lipat, sepeda jalan raya, dan lain-lain. Jenis sepeda yang berbagai macam tersebut membuat tiap-tiap jenis sepeda memiliki ciri khas untuk membedakan dengan jenis sepeda yang lain. Meskipun demikian, tidak mengubah fungsi sepeda yaitu sebagai sarana transportasi bagi manusia untuk menghubungkan perpindahannya dari satu daerah ke daerah lain.

Salah satu jenis sepeda adalah sepeda fixed gear atau masyarakat awam mengenal dengan sebutan sepeda Fixie. Sepeda fixed gear identik dengan jenis sepeda yang menarik dari segi warnanya, tanpa rem, dan tanpa gear dinamis atau gear mati. Sepeda ini menggunakan sistem fixed gear yang membuat ayunan pedal terus berputar seiring perputaran roda belakang. Menghentikan laju sepeda ini ketika berjalan atau melakukan pengereman pengendara harus mengurangi putaran pedal dengan gaya melawan arah perputaran pedal atau sistem door trape. Sistem door trape pada sepeda fixed gear justru membahayakan bagi pengendaranya ketika bersepeda.

\section{Tujuan Penelitian}

Tujuan penelitian ini di harapan mewujudkan masyarakatt yang berbudaya dan kota yang berwawasan lingkungan. Penggunaan sepeda untuk mengurangi penggunaan motoris perlu di sikapi dengan penerapan jalur sepeda berdasarkan kebutuhan dan kreteria yang sesuai untuk kota sorong.

\section{STATE OF THE ART}

Adapun penelitian terdahulu yang terkait dengan penelitian ini adalah sebagai berikut :

1. Menurut Andrade,katia dan seiichi kagaya "cyclists behaviour idfication of factors on communiting by bicyle mobilidade,cidade a territotia paranoa 9 ( 2013 )

2. Dipartemen pekerjaan umum direktorat jendral Bina Marga, Undang-undang republic Indonesia Nomor 22 Tahun 2009 tentang lalulintas dan angkutan jalan.

3. Kementrian Pekerjaan umum badan penelitian dan pengembangan. Modul pelatihan perancangan jalur sepeda

\section{METODE}

\section{Tahapan Penelitian}

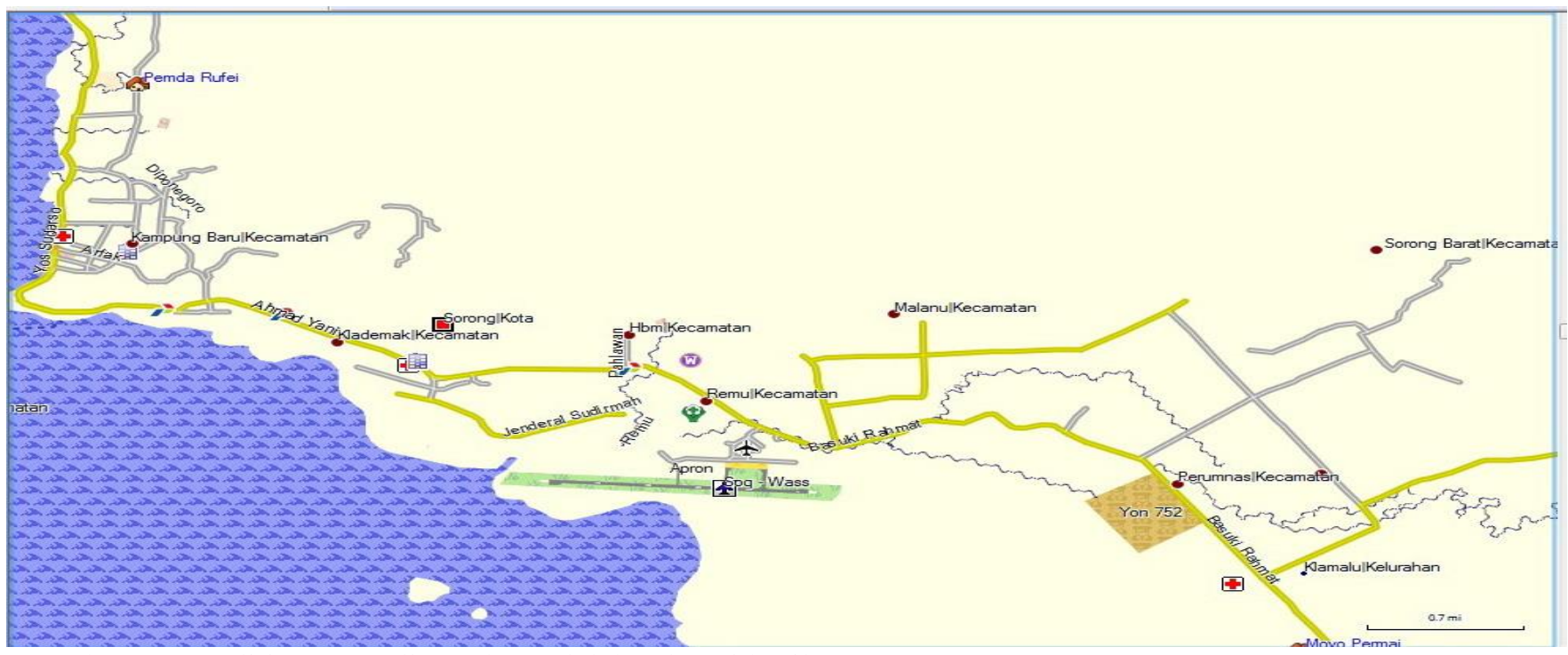

Tahapan penelitian yang digunakan adalah sebagai berikut :

1. Melakukan pengamatan langsung terhadap jalan raya di wilayah Kota Sorong

2. Mengolah data dari hasil yang telah di dapatkan pada saat melakukan pengamatan langsung .

3. Mengidentifikasi dan menganalisa permasalahan jalur sepeda yang terjadi diKota Sorong.

Semua metode penulisan dan analisa dalam artikel ilmiah ini merujuk pada panduan penulisan tugas akhir Fakultas Teknik Universitas Muhammadiyah Sorong tahun 2014 (Pristianto, Amri, \& Rusdi, 2014). 


\section{REFERENSI}

Artina Ningsih (2011). JALUR SEPEDA SEBAGAI BAGIAN DARI SISTEM TRANPORTASI KOTA YANG BERWAWASAN LINGKUNGAN.

Yoga Pranata(2017). KAJIAN PENYEDIAAN LAJUR SEPEDA DI LINGKUNGAN UNIVERSITAS BRAWIJAYA

Riyanawati,W.N (2011) Penentuan prioritas penyediaan lajur sepeda di kota malang dengan metode Analytic Hierarchy Process.

Mohammad Muktiali (2011) KAJIAN PELUANG PENERAPAN JALUR SEPEDA DI KOTA MALANG

DESSYANA RAHMAWATI (2014) UNIVERSITAS GAJAH MADA : Rencana Fasilitas Sepeda Kota Yogyakarta.

Pristianto, H., Amri, I., \& Rusdi, A. (2014, May 9). Pedoman Penulisan Tugas Akhir Fakultas Teknik Universitas Muhammadiyah Sorong 2014. http://doi.org/10.17605/OSF.IO/4VTJM. 